\title{
Patterns of litter production in a secondary alluvial Atlantic Rain Forest in southern Brazil ${ }^{1}$
}

\author{
MAURÍCIO BERGAMINI SCHEER ${ }^{1,2,3,7}$, GUSTAVO GATTI ${ }^{4}$, CELINA WISNIEWSKI ${ }^{3}$, \\ ALAN YUKIO MOCOCHINSKI ${ }^{5}$, ANDRÉ TARGA CAVASSANI ${ }^{6}$, ALEXANDRE LORENZETTO ${ }^{6}$ \\ and FRANCISCO PUTINI ${ }^{6}$
}

(received: April 3, 2008; accepted: September 23, 2009)

\begin{abstract}
Patterns of litter production in a secondary alluvial Atlantic Rain Forest in southern Brazil). Above-ground litter production is one of the most accessible ways to estimate ecosystem productivity, nutrient fluxes and carbon transfers. Phenological patterns and climatic conditions are still not fully explained well for tropical and subtropical forests under less pronounced dry season and non-seasonal climates, as well as the interaction of these patterns with successional dynamics. Monthly litterfall was estimated for two years in a 9 to 10 year old secondary alluvial Atlantic Rain forest. Total litterfall was higher in the site with more developed vegetation $\left(6.4 \pm 1.2\right.$ ton $\mathrm{ha}^{-1}$ year $^{-1}$; $95 \%$ confidence interval) as compared to the site with less developed vegetation $\left(3.0 \pm 1.0\right.$ ton ha $^{-1}$ year $^{-1}$ ). The monthly production of 11 litter fractions (eight fractions comprising the leaf litter of the seven main species of the community and other species; reproductive parts, twigs $\leq 2 \mathrm{~cm}$ diameter, and miscellaneous material) were correlated with meteorological variables making possible to identify three patterns of deposition. The main pattern, dominated by leaf-exchanging species, consisted of a cycle with the highest litterfall at the beginning of the rainy season, preceding by basically three months the peaks of the annual cycles of rainfall and temperatures. Other two patterns, dominated by brevi-deciduous species, peaked at the end of the rainy season and at the end of the non-rainy season. Tropical and subtropical dry forests that present the highest leaf fall gradually earlier than rain forests (as the studied sites) are possibly related to the start of senescence process. It seems that such process is triggered earlier by a more severe hydric stress, besides other factors linked to a minor physiological activity of plants that result in abscission.
\end{abstract}

Key words - litterfall, meteorological variables, phenology, primary productivity, sucession

RESUMO - (Padrões de produção de serapilheira em uma Floresta Ombrófila Densa aluvial secundária no Sul do Brasil). A produção de serapilheira é uma das variáveis mais acessíveis para se estimar a produtividade primária, fluxos de nutrientes e transferências de carbono em ecossistemas terrestres. Padrões fenológicos e condições climáticas ainda não estão bem explicados para florestas tropicais e subtropicais sob climas com sazonalidade pouco pronunciada, muito menos a interação desses padrões com a dinâmica sucessional. A produção mensal de serapilheira foi estimada durante dois anos em uma Floresta Ombrófila Densa aluvial durante o nono e décimo ano de regeneração. O sítio com vegetação mais desenvolvida apresentou maior produção de serapilheira $\left(6,4\right.$ ton $\left.\mathrm{ha}^{-1} \mathrm{ano}^{-1}\right)$, quando comparado com o sítio com vegetação menos desenvolvida (3,0 ton ha $^{-1}$ ano $\left.^{-1}\right)$. As produções mensais de 11 frações de serapilheira foram correlacionadas com variáveis meteorológicas possibilitando identificar três padrões de deposição. O padrão principal, dominado por espécies sempre verdes, consistiu em um ciclo anual com maior produção de serapilheira no início da estação quente e chuvosa (primavera), precedendo aproximadamente três meses os picos dos ciclos de temperatura e de precipitação pluviométrica. Para os outros dois padrões, dominados por espécies breve-decíduas, os picos de produção ocorreram no final da estação chuvosa (verão) e no final da estação com menor precipitação pluviométrica (inverno). Florestas tropicais e subtropicais com sazonalidade marcante (períodos secos) possivelmente apresentam maior deposição de folhas mais cedo que florestas úmidas (como os sítios estudados) devido ao início do processo de senescência foliar. Tal processo parece ser desencadeado mais cedo por um estresse hídrico mais severo, além de outros fatores ligados à menor atividade fisiológica das plantas que resultam na abscisão.

Palavras-chave - fenologia, produção de serapilheira, produtividade primária, sucessão, variáveis meteorológicas

1. Part of a M.Sc. dissertation of the first author performed at the Programa de Pós-Graduação em Engenharia Florestal, Universidade Federal do Paraná,

2. Sanepar/DMA, Assessoria de Pesquisa e Desenvolvimento, Rua Engenheiros Rebouças, 1376, Rebouças, 80215-900 Curitiba, PR, Brazil.

3. Universidade Federal do Paraná, Programa de Pós-Graduação em Engenharia Florestal, Av. Pref. Lothário Meissner, 900, Jardim Botânico - Campus III, 80210-170 Curitiba, PR, Brazil.
4. Fundação O Boticário de Proteção à Natureza, Rua Gonçalves Dias, 225, Batel, 80240-340 Curitiba, PR, Brazil.

5. Coordenação de Aperfeiçoamento de Pessoal de Nível Superior, MEC, Esplanada dos Ministérios, bloco L, anexo II, sala 204, 70359-970 Brasília, DF, Brazil.

6. Rede Pró-Unidades de Conservação, Rua Schiller, 702b, Cristo Rei, 80050-260 Curitiba, PR, Brazil.

7. Corresponding author: mauriciobs@sanepar.com.br 


\section{Introduction}

A large part of the original Atlantic Rain Forest is located along the Brazilian coastline and referred to as the Dense Ombrophylous Forest, according to Veloso et al. 1991. In the state of Paraná (Southern Brazil), this phytogeographic formation can be divided into many forest types due to environmental differences (e.g., soil, topography) among sites. Different plant communities occur from coastal plains to the western slopes of Serra do Mar, towards the ecotone with the Mixed Ombrophylous Forest (Araucaria Forest). Most of the Atlantic rain forests is nowadays in the early and intermediate stages of secondary succession due to the past of deforestation and soil degradation. Today only $7.5 \%$ of the Brazilian Atlantic Forest (a hotspot for conservation) original cover remains (Myers et al. 2000). Including intermediate secondary forests and small fragments $(<100 \mathrm{ha})$ this percentage increases, ranging from 11.4 to $16 \%$ (Ribeiro et al. 2009). In the state of Paraná the situation is similar with a forest cover reduction to 9\% (Fundação SOS Mata Atlântica 1998). Among Atlantic rain forest types, the alluvial formation is the most degraded (Sema 2002).

Several authors (e.g., Golley et al. 1978, Varjabedian \& Pagano 1988) emphasize the need to understand these ecosystems and the restoration mechanisms to recover pre-existing primary productivity, biodiversity and genetic fluxes. Above-ground litter production is one of the most accessible ways to estimate ecosystem productivity and nutrient fluxes (Brown \& Lugo 1982, Sampaio et al. 1993). Therefore, many studies estimated litter production in different regions of the world, mainly tropical and temperate forests (Bray \& Gorham 1964, Vitousek 1984, Vogt et al. 1986). In Brazilian Atlantic rain forests litterfall studies have been published (Jackson 1978, Varjabedian \& Pagano 1988, Sampaio et al. 1993, Leitão-Filho et al. 1993, Oliveira \& Lacerda 1993, Custódio-Filho et al. 1996, Mazurec \& Villela 1998, Louzada 1997, Domingos et al. 1997, Moraes et al. 1999, Domingos et al. 2000, Portes 2001, GamaRodrigues \& Barros 2002, Pinto \& Marques 2003, Britez et al. 2005, Pires et al. 2006) but data on vegetation growing on alluvial soils are scarce or non-existent, despite their critical situation. Those studies demonstrate the importance of this kind of research. Comparisons among ecosystems provide diagnosis of the succession and the need of intervention for restoration depending of their resilience level.

Monitoring of phenological patterns can also be achieved through litterfall studies. Many phenological and litterfall studies used correlations to detect synchronies among biological and meteorological cycles, without the pretension of explaining relations of cause and effect through these analyses (Morellato et al. 2000, Talora \& Morellato 2000, Marques et al. 2004, Marques \& Oliveira 2004, Chapman et al. 2005). According to Morellato et al. (2000) those relationships remain ambiguous for tropical forests under less and non-seasonal climates where even simple patterns of flowering, fruiting or formation of new leaves are hardly understood, much less the interaction of these patterns with successional dynamics.

Generally, abscission in evergreen rain forests (lacking a strong dry season) occurs with more intensity when there is an increase of day length, solar radiation, air relative humidity, rainfall and consequent leaf flush (Larcher 1986, van Schaik et al. 1993). This is also observed in several litterfall studies in Atlantic rain forests in Brazil (Jackson 1978, Sampaio et al. 1993, Custódio-Filho et al. 1996, Moraes et al. 1999, Portes 2001, Britez et al. 2005). However, each plant community is comprised by many species, each one with different cycles and responses to its environment.

This study is part of a medium term research on successional dynamics of an alluvial Atlantic rain forest (called Succession Project) at the Salto Morato Natural Reserve (RNSM). This paper reports: 1 ) the production of above-ground components of litter; 2) the classification of the litter fractions in main seasonal patterns through the search of temporal distances among litterfall and meteorological annual cycles.

\section{Material and methods}

The study area - The alluvial forest is located at the RNSM at an altitude of $20 \mathrm{~m}$, in the municipality of Guaraqueçaba, on the northeastern coast of Paraná, Brazil $\left(25^{\circ} 10^{\prime} 45^{\prime \prime} \mathrm{S}\right.$ and $\left.48^{\circ} 17^{\prime} 48^{\prime \prime} \mathrm{W}\right)$. The climate can be classified as Cfa, or subtropical, according to Köppen System (Iapar 2005). Daily mean temperature in the coldest month is less than $18^{\circ} \mathrm{C}$ and the mean temperature in the warmest month is higher than $22^{\circ} \mathrm{C}$, with hot and wet summers (January-March), and a relatively non-pronounced dry season. Mean annual rainfall is at least 2,000 mm (Iapar 2005). Maack (1968) considered the region as having a transitional tropical climate.

This is a representative forest of the alluvial plains and is the typical successional stage found along the extensive Brazilian coastline. The Guaraqueçaba region is considered an Unesco World Heritage Site for comprising significant remnants of the endangered Atlantic Rain Forest. Cenozoic sediments originated from Serra do Morato (uplifted blocks of igneous and high-grade metamorphic rocks), driven by 
highly variable energy transport and a low level water table, resulted in an alluvial plain (figure 1 ) with a mosaic-like soil distribution. The specific area (7 ha) was investigated during the $9^{\text {th }}$ and $10^{\text {th }}$ year after ceasing water-buffalo grazing.

An area between the early and intermediate secondary successional stage over medium textured Fluvisols and Cambisols (according to World Reference Base for Soil Resources - FAO-WRB, Embrapa 2006) was selected, in which vegetation structure showed different levels of regeneration, although buffalo grazing was stopped at the same time.

The area was stratified into two sites according to different levels of regeneration classified through tree abundance and basal areas to reduce sampling errors (Gatti et al. unpublished data). Both areas, here assumed as more and less developed sites, were sampled 9-10 years after water buffalos were removed.

Site 1: The more developed vegetation - It is located closer to an advanced secondary successional stage of a lower montane rain forest (about $100 \mathrm{~m}$ far), a major propagules source. The number of trees estimated in $10\left(100 \mathrm{~m}^{2}\right)$ plots (perimeter at breast height $\geq 10 \mathrm{~cm}$ ) was 2,820 individuals $\mathrm{ha}^{-1}$ and the basal area was $22.2 \mathrm{~m}^{2} \mathrm{ha}^{-1}$ in a total of 36 species (Gatti et al. unpublished data). The canopy (about $8 \mathrm{~m}$ tall) is dominated by Myrsine coriacea (Sw.) R. Br. ex Roem. \& Schult., Senna multijuga (Rich.) H. S. Irwin \& Barneby, Cecropia pachystachya Trécul and Tibouchina pulchra Cogn. Among shrubs, Piper aduncum L. and Boehmeria caudata Sw. are frequent species. In the herbaceous stratum,
Cyrtocymura scorpioides (Lam.) H. Rob. and Manettia congesta (Vell.) K. Schum. are widespread. The presence of seedlings of species that will probably dominate the community in the next successional stage, such as Hyeronima alchorneoides Allemão and Vochysia bifalcata Warm., was also observed.

Site 2: less developed vegetation - The number of trees and basal area were lower than in site 1 , respectively 1,130 individuals ha ${ }^{-1}$ and $6.7 \mathrm{~m}^{2} \mathrm{ha}^{-1}$, comprising 24 woody species (Gatti et al. unpublished data). This area, occurring in average $200 \mathrm{~m}$ far of the secondary forest, supports the same species as site 1 although trees are sparsely distributed, rarely forming a continuous canopy. Shrubs such as Vernonanthura beyrichii (Less.) H. Rob. and Solanum fastigiatum Willd. are frequent. The herbaceous community is dominated by C. scorpioides, Paspalum wettsteinii Hack. and, Brachiaria mutica (Forsk.) Stapf. Indroduced Brachiaria spp. from neighboring areas with Hydromorphic Histosols, in some cases, invaded this site delaying the succession process.

Litterfall collections - In each site, thirty $0.5 \mathrm{~m}^{2}$ circular litter traps were placed ( $1 \mathrm{~m}$ above soil surface level) in 10 $\left(100 \mathrm{~m}^{2}\right)$ plots of a previous forest structure and composition study (Gatti 2000). Above-ground litterfall was collected every two weeks from September 2001 to September 2003. The fallen material of three traps in each plot was collected and pooled on a "monthly" basis (28 days) and considered a replicate $(n=10)$. After previous air drying, each sample was sorted into four groups (leaves, reproductive parts, twigs

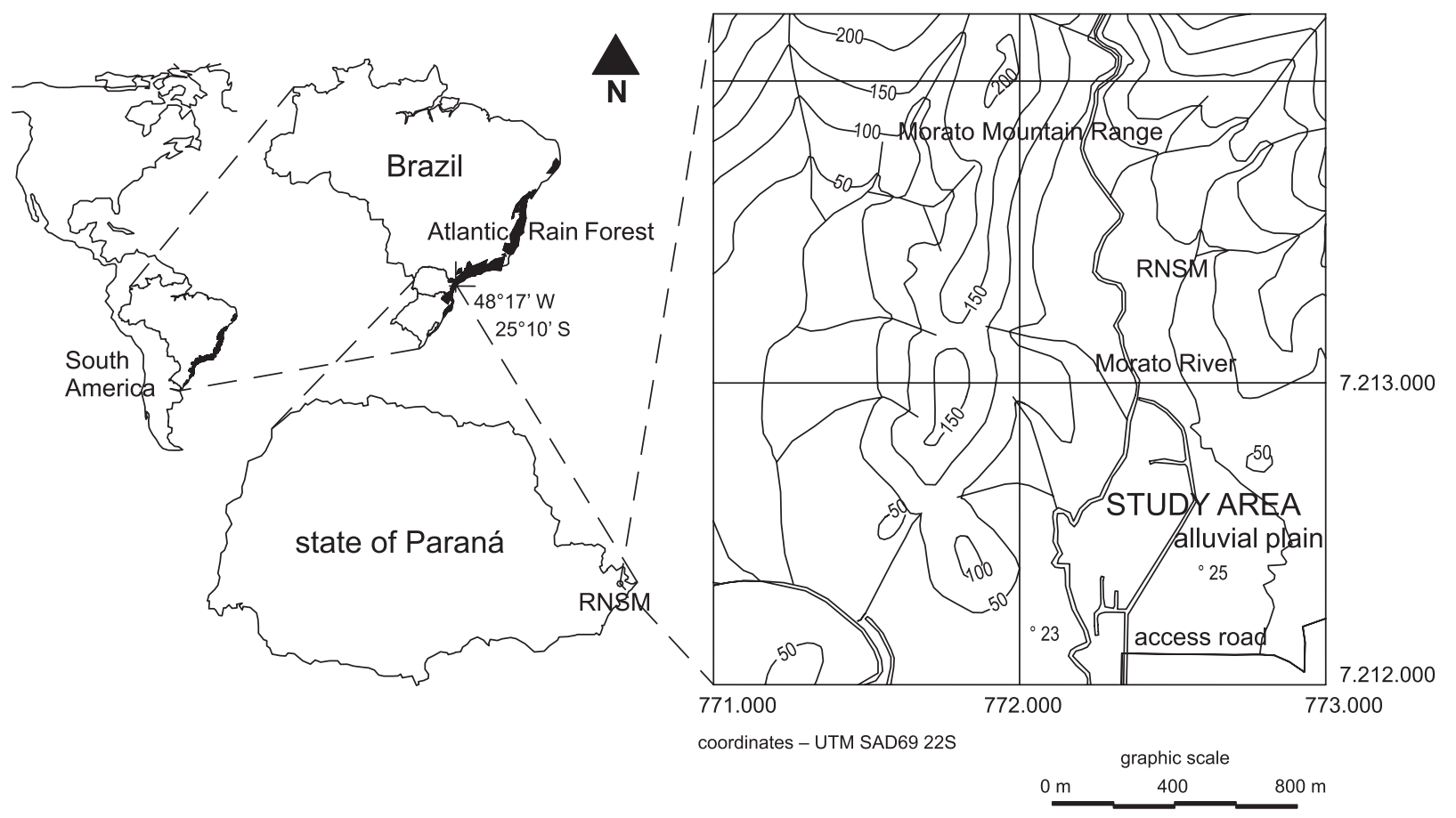

Figure 1. Geographic location of the alluvial plain at Salto Morato Natural Reserve (RNSM), Guaraqueçaba, state of Paraná, Brazil. 
$\leq 2 \mathrm{~cm}$ diameter, and miscellaneous material). Leaves were split into eight sub-fractions: seven according to the species of more expressive abundance (Myrsine coriacea, Myrsinaceae; Alchornea glandulosa Poepp., Euphorbiaceae; Psidium guajava L. (exotic species), Myrtaceae; Senna multijuga, Leguminosae; Cecropia pachystachya, Cecropiaceae; Tibouchina pulchra, Melastomataceae and Citharexylum myrianthum Cham., Verbenaceae) and one comprising leaves from all other species of the community. All fractions were oven-dried at $65^{\circ} \mathrm{C}$ for at least $72 \mathrm{~h}$ and weighted.

Meteorological data - Mean monthly minimum, mean and maximum temperatures $\left({ }^{\circ} \mathrm{C}\right)$, insolation $\left(\mathrm{h} \mathrm{day}^{-1}\right)$ and relative humidity (\%) and monthly rainfall ( $\mathrm{mm}$ ) data from the nearest climatic station with similar conditions (40 m of altitude and $26 \mathrm{~km}$ far from study area) were used for correlation calculations. Historical data from the last 20 years were also used. Data were made available by Meteorological Service of State of Paraná (Simepar). Mean monthly rainfall was also measured in the study area using six $12.5 \mathrm{~cm}$ diameter, polyethylene funnels connected into five liter polyethylene bottles. Each apparatus was mounted in a PVC tube so that each funnel rim was around $1 \mathrm{~m}$ above the soil surface (Scheer 2009). Rainfall was measured every two weeks corresponding to the same interval of litterfall collection. A test comparing daily measures indicated little evaporation occurred. Rainfall data from the study area presented high correlation with rainfall measured by the official meteorological station and therefore were used in correlation calculations $\left(r_{s}=0.937\right.$, $P<0.00)$.

Statistical analyses - Data on litter production were extrapolated to $\mathrm{kg} \mathrm{ha}^{-1}$. Sample errors of stratified means with 95\% confidence intervals were estimated. Statistical significance of the differences between means was tested by the $t$-test, ANOVA and Duncan's test. Data were lntransformed whenever necessary to fit normality, homogeneity of variance and other conditions. Spearman's rank correlation coefficients $\left(r_{s}\right)$ were calculated according to Zar (1999) to correlate litter components produced along the months (considering the mean of the two sites due to the similar behavior and to simplify the results) with meteorological variables. Similar non-parametric correlations are also used in many phenological and litterfall studies (Morellato et al. 2000, Talora \& Morellato 2000, Marques et al. 2004, Marques \& Oliveira 2004, Chapman et al. 2005).

Considering that leaf abscission is the last step in a planned senescence process within tree leaves (Coder 1999), climatic factors can trigger physiological changes at the start of a planned senescence, a process that needs some time to complete abscission. Therefore, the temporal distances among the analysed cycles were detected through the search of the highest coefficients found through the dislocation of the data sequence of 24 months of production of each litter fraction to match with the data sequence of the 24 months of each meteorological variable (dislocations varying from \pm 1 to \pm 13 months). Litterfall data of the two studied years were also related with meteorological historical data for the last 20 years and similar patterns and correlation coefficients were observed (data not presented).

\section{Results}

Litterfall and its components - The total annual litterfall in the more developed site was $6.4 \pm 1.2$ ton $\mathrm{ha}^{-1}$ and the less developed site was only $3.0 \pm 1.0$ ton ha ${ }^{-1}$ (table 1 ). In the first year, total litter production in less developed site was only $42 \%$ ( 2.7 ton $\left.\mathrm{ha}^{-1}\right)$ of the total produced in more developed site. In the second year, a significant increase $(P<0.01)$ to $53 \%$ (3.4 ton ha $\left.{ }^{-1}\right)$ was observed. In plots of site 1 , leaf litter comprised $69 \%$ of total litter production (tables 2 and 3). Twigs contributed 22\%, reproductive parts comprised $4 \%$ and miscellaneous material made up $5 \%$ of litterfall. In site 2, leaf litter contributions increased to $80 \%$ while twigs decreased to $11 \%$; reproductive parts and miscellaneous material contributed $6 \%$ and $3 \%$ respectively (table 2 ).

Table 1 . The mean $(n=10)$ monthly values $\left(\mathrm{kg} \mathrm{ha}^{-1} \pm \mathrm{SE}\right)$ of litter production, measured from each of 10 plots (three traps per plot) at each site at RNSM, Guaraqueçaba, Paraná, Brazil. Mean of a 2-year sample.

\begin{tabular}{lcccc}
\hline Date & & Site 1 & & Site 2 \\
\cline { 1 - 1 } September 23 & Mean \pm SE & & Mean \pm SE \\
\cline { 1 - 2 } October 19 & $670 \pm 66$ & & $295 \pm 60$ \\
November 16 & $469 \pm 42$ & & $278 \pm 41$ \\
December 15 & & $760 \pm 93$ & & $365 \pm 76$ \\
January 12 & & $512 \pm 49$ & & $287 \pm 38$ \\
February 09 & $579 \pm 86$ & & $271 \pm 54$ \\
March 09 & $515 \pm 55$ & & $212 \pm 33$ \\
April 06 & $369 \pm 41$ & & $176 \pm 33$ \\
May 03 & $344 \pm 40$ & & $168 \pm 33$ \\
June 02 & & $485 \pm 55$ & & $205 \pm 39$ \\
June 29 & $355 \pm 32$ & & $173 \pm 43$ \\
July 27 & $351 \pm 45$ & & $157 \pm 28$ \\
August 24 & $466 \pm 49$ & & $211 \pm 35$ \\
September 21 & $492 \pm 54$ & & $213 \pm 33$ \\
\hline Mean of 13 (28-d) periods & $490 \pm 54$ & & $232 \pm 42$ \\
Monthly means & 531 & & 251 \\
Total first studied year & $6388 \pm 592$ & & $2673 \pm 438$ \\
Total second studied year & $6345 \pm 505$ & & $3349 \pm 492$ \\
TOTAL ANNUAL & $6367 \pm 523$ & & $3011 \pm 426$ \\
\hline Lower limit (95\% CI) & 5185 & 2048 \\
\hline Upper limit (95\% CI) & 7549 & 3974 \\
\hline
\end{tabular}


Table 2. Litterfall fractions ( $\mathrm{kg} \mathrm{ha}^{-1} \mathrm{year}^{-1} \pm \mathrm{SE}$ ) in each site, at RNSM, Guaraqueçaba, Paraná, Brazil. Mean of a 2-year sample $(n=10)$, ( $\mathrm{L}=$ leaf litterfall).

\begin{tabular}{|c|c|c|}
\hline \multirow{2}{*}{ Litterfall fractions } & Site 1 & Site 2 \\
\hline & Mean \pm SE & Mean \pm SE \\
\hline Twigs ( $\leq 2$ cm) & $1396 \pm 240$ & $335 \pm 111$ \\
\hline Reproductive parts & $285 \pm 46$ & $184 \pm 42$ \\
\hline Miscellaneous & $326 \pm 44$ & $93 \pm 17$ \\
\hline $\begin{array}{l}\text { Leaves of other spp. } \\
\text { including* }\end{array}$ & $1965 \pm 319$ & $455 \pm 82$ \\
\hline L. M. coriacea & $658 \pm 103$ & $288 \pm 91$ \\
\hline L. A. glandulosa & $244 \pm 83$ & $10 \pm 4$ \\
\hline L. P. guajava & $318 \pm 129$ & $76 \pm 47$ \\
\hline L. S. multijuga & $408 \pm 99$ & $159 \pm 40$ \\
\hline L. C. pachystachya & $391 \pm 130$ & $844 \pm 139$ \\
\hline L. T. pulchra & $376 \pm 234$ & $567 \pm 203$ \\
\hline Total of 6 species & $2395 \pm 179$ & $1943 \pm 264$ \\
\hline L. C. myrianthum** & $(616 \pm 149)$ & $(204 \pm 64)$ \\
\hline Total leaf litterfall & $4360 \pm 267$ & $2398 \pm 305$ \\
\hline TOTAL & $6367 \pm 523$ & $3011 \pm 426$ \\
\hline
\end{tabular}

* C. myrianthum. ** Leaves of C. myrianthum were sampled separately only in the second year.
The amount of leaves of the seven studied species represented $47 \%$ of total litterfall in site 1 , while other species contributed $22 \%$ of total litterfall and $32 \%$ of leaf litter. In site 2, leaves of selected species had a higher contribution (79\%) while other species contributed only $1 \%$ and $1.3 \%$ respectively, reflecting the lower diversity of woody species. In site $1, M$. coriacea was the species with the larger contribution for leaf fall, followed by C. myrianthum, S. multijuga, C. pachystachya and T. pulchra, $P$. guajava and A. glandulosa making up 68\% of total leaf fall. In site 2, major leaf fall came from C. pachystachya and T. pulchra, demonstrating their greater importance in this community. Absolute leaf deposition of $C$. pachystachya in site 2 was twice as high compared to the more developed site (844 kg ha-1 year $^{-1}$ against

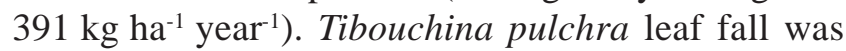
$50 \%$ higher in the less developed site (567 kg ha-1 year-1 against $376 \mathrm{~kg} \mathrm{ha}^{-1}$ year $^{-1}$ ) (table 2).

Litterfall seasonal patterns and their relationships with meteorological variables - Annual average rainfall in the study area was $2676 \mathrm{~mm}$ during the period of this study, with no differences between years $(P<0.01)$. Monthly litterfall and meteorological data over the two years are presented in figure 2 . The highest rainfall rates

Table 3. Litter production in some Brazilian Atlantic rain forests. (Sa = sampling area size. Forest types: Restinga $=$ sandy coastal plain forest; LRF = lowland rain forest; $\mathrm{ARF}=$ alluvial rain forest; $\mathrm{LMRF}=$ lower montane rain forest; $\mathrm{MRF}=\mathrm{montane}$ rain forest; UMRF = upper montane rain forest.)

\begin{tabular}{|c|c|c|c|c|c|c|c|}
\hline $\begin{array}{l}\text { Type of } \\
\text { forest / site }\end{array}$ & Observations & Brazilian state & $\begin{array}{l}\text { Elev. } \\
(\mathrm{m})\end{array}$ & $\begin{array}{c}\mathrm{Sa} \\
\left(\mathrm{m}^{2}\right)\end{array}$ & $\begin{array}{c}\text { Litterfall } \\
\left(\mathrm{kg} \mathrm{ha}^{-1} \text { year }^{-1}\right)\end{array}$ & $\begin{array}{c}\text { Leaves } \\
(\%)\end{array}$ & $\begin{array}{c}\text { Peak } \\
\text { (rainy season) }\end{array}$ \\
\hline Restinga $^{1}$ & - & São Paulo & 5 & 7.5 & 3900 & 75 & beginning \\
\hline Restinga $^{2}$ & Between beach ridge & Paraná & 5 & 15.0 & 7673 & 59 & beginning \\
\hline Restinga $^{2}$ & On beach ridge & Paraná & 5 & 15.0 & 5235 & 62 & beginning \\
\hline Restinga*3 & - & Rio de Janeiro & 5 & - & 6200 & 68 & - \\
\hline Restinga $^{4}$ & On beach ridge & Paraná & 5 & 10.0 & 5080 & 75 & beginning \\
\hline $\mathrm{LRF}^{5}$ & Early successional & Paraná & 5 & 3.1 & 5400 & 86 & intermediate \\
\hline $\mathrm{LRF}^{5}$ & Mid successional & Paraná & 5 & 3.1 & 7600 & 73 & intermediate \\
\hline $\mathrm{LRF}^{5}$ & Late successional & Paraná & 5 & 3.1 & 6400 & 67 & intermediate \\
\hline $\mathrm{LRF}^{6}$ & - & Bahia & 5 & - & 9400 & 94 & intermediate \\
\hline $\mathrm{LRF}^{7}$ & Mature forest & Espírito Santo & 40 & 15.0 & 8500 & 70 & beginning \\
\hline $\mathrm{LRF}^{7}$ & Late successional & Espírito Santo & 40 & 15.0 & 8400 & 61 & beginning \\
\hline ARF & Site 1 - This study & Paraná & 40 & 15.0 & 6367 & 69 & beginning \\
\hline ARF & Site 2 - This study & Paraná & 40 & 15.0 & 3011 & 80 & beginning \\
\hline $\mathrm{LMRF}^{8}$ & - & São Paulo & 140 & 2.5 & 7925 & 64 & end \\
\hline $\mathrm{LMRF}^{1}$ & Mature forest & São Paulo & 140 & 7.5 & 6300 & 70 & beginning \\
\hline $\mathrm{LMRF}^{9}$ & Mature forest & Rio de Janeiro & 50 & 3.0 & 9460 & 69 & beginning \\
\hline $\mathrm{LMRF}^{9}$ & Mature forest & Rio de Janeiro & 200 & 3.0 & 9060 & 64 & $\begin{array}{l}\text { beginning } \\
\text { continue }\end{array}$ \\
\hline
\end{tabular}


continuation

\begin{tabular}{|c|c|c|c|c|c|c|c|}
\hline $\begin{array}{l}\text { Type of } \\
\text { forest / site }\end{array}$ & Observations & Brazilian state & $\begin{array}{l}\text { Elev. } \\
(\mathrm{m})\end{array}$ & $\begin{array}{l}\mathrm{Sa} \\
\left(\mathrm{m}^{2}\right)\end{array}$ & $\begin{array}{c}\text { Litterfall } \\
\left(\mathrm{kg} \mathrm{ha}^{-1} \text { year }^{-1}\right)\end{array}$ & $\begin{array}{l}\text { Leaves } \\
(\%)\end{array}$ & $\begin{array}{c}\text { Peak } \\
\text { (rainy season) }\end{array}$ \\
\hline LMRF*10 & Affected by pollution & São Paulo & 140 & 2.5 & 7748 & 79 & beginning \\
\hline $\mathrm{LMRF}^{11}$ & Affected by pollution & São Paulo & 350 & 16.0 & 5289 & - & - \\
\hline LMRF $^{11}$ & Mid successional & São Paulo & 120 & 8.0 & 5682 & - & - \\
\hline LMRF $^{11}$ & Mid successional & São Paulo & 250 & 8.0 & 4460 & - & - \\
\hline LMRF $^{10}$ & - & São Paulo & 150 & 2.5 & 8265 & 67 & beginning \\
\hline $\mathrm{MRF}^{10}$ & Affected by pollution & São Paulo & 800 & 2.5 & 6835 & 75 & beginning \\
\hline $\mathrm{MRF}^{12}$ & - & Rio de Janeiro & 750 & 9.0 & 8900 & 74 & intermediate \\
\hline $\mathrm{MRF}^{13}$ & Affected by pollution & São Paulo & - & 11.0 & 6054 & 73 & beginning \\
\hline $\mathrm{MRF}^{14}$ & Mature forest & Espírito Santo & 850 & 37.4 & 4500 & - & end \\
\hline $\mathrm{MRF}^{15}$ & Mid successional & São Paulo & 800 & 7.5 & 7007 & 72 & beginning \\
\hline MRF $^{15}$ & Affected by pollution & São Paulo & 800 & 6.3 & 1803 & - & - \\
\hline $\mathrm{MRF}^{15}$ & Affected by pollution & São Paulo & 800 & 6.3 & 3810 & - & - \\
\hline $\mathrm{UMRF}^{16}$ & Mature forest & Paraná & 1300 & 3.9 & 4500 & 63 & beginning \\
\hline
\end{tabular}

${ }^{1}$ Moraes et al. (1999); ${ }^{2}$ Britez et al. (2005); ${ }^{3}$ Ramos \& Pellens (1994)*; ${ }^{4}$ Pires et al. 2006; ${ }^{5}$ Pinto \& Marques (2003); ${ }^{6}$ Gama-Rodrigues \& Barros (2002); ${ }^{7}$ Louzada (1997); ${ }^{8}$ Varjabedian \& Pagano (1988); ${ }^{9}$ Mazurec \& Villela (1998); ${ }^{10}$ Lopes et al. (1993)*; ${ }^{11}$ Leitão Filho et al. (1993); ${ }^{12}$ Oliveira \& Lacerda (1993);

${ }^{13}$ Custódio Filho et al. (1996); ${ }^{14}$ Jackson (1978); ${ }^{15}$ Domingos et al. (1997); ${ }^{16}$ Domingos et al. (2000); ${ }^{17}$ Portes (2001). *Listed by Moraes et al. (1999).
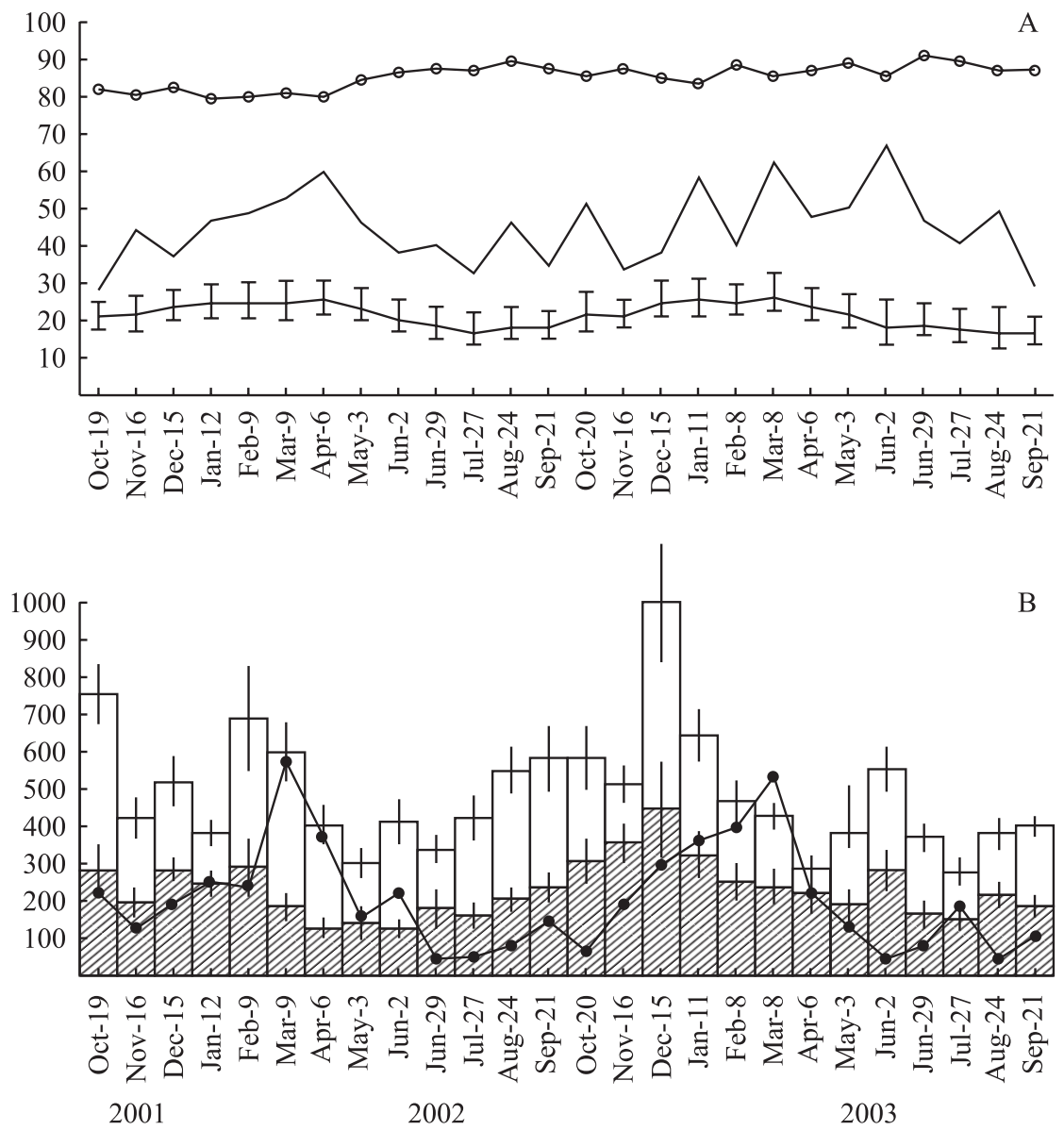

Figure 2. A. Mean monthly values of minimum, mean and maximum temperatures ( $\left.\mathrm{I} ;{ }^{\circ} \mathrm{C}\right)$, insolation $\left(-; \mathrm{h} \mathrm{d}^{-1}\right)$ and relative humidity ( - ; \%) of the studied period, assigned by Simepar, Iapar’s Guaraqueçaba station, at $40 \mathrm{~m}$ elevation at $26 \mathrm{~km}$ far from study area. B. Seasonal patterns of total litterfall $\left(\mathrm{kg} \mathrm{ha}^{-1}, n=10\right.$ per site; 四 = site 1 ; 四 = site 2; | = standard error $)$ and rainfall $(\bullet \bullet ; \mathrm{mm})$ in the study area, at RNSM, Guaraqueçaba, Paraná, Brazil. 
occurred in February 2002 (measured from February 9 to March $9=572 \mathrm{~mm}$ ) and the lowest ones in June 2002 (47 mm). The highest litterfall occurred undoubtedly in December of the second year $\left(1,000 \mathrm{~kg} \mathrm{ha}^{-1}\right.$, site 1) (figure 2). Statistical significant differences were detected between total litterfall in the rainy season (October - March) as compared to the non-rainy season (April - September) at site $1(P<0.01)$ and at site $2(P=0.055)$. The seasonal behavior of the litter components is shown in figure 3. As already commented, leaf litter represents the major part of the litter production and then can be interpreted in the same figure.
The strongest correlations, either positive or negative, of monthly litterfall with meteorological data were not observed when comparing data from the corresponding months but did exist for data of previous and/or subsequent months. This resulted in three different correlation patterns, fitting the litterfall components (simplified in table 4). The goal here was to report the studied stage of succession and, therefore, two years of measurements can be considered sufficient. It is important to emphasize that correlation analysis do not indicate cause and effect; they only point out similarity in behavior among data sets, providing insights for interpretation of phenological patterns.

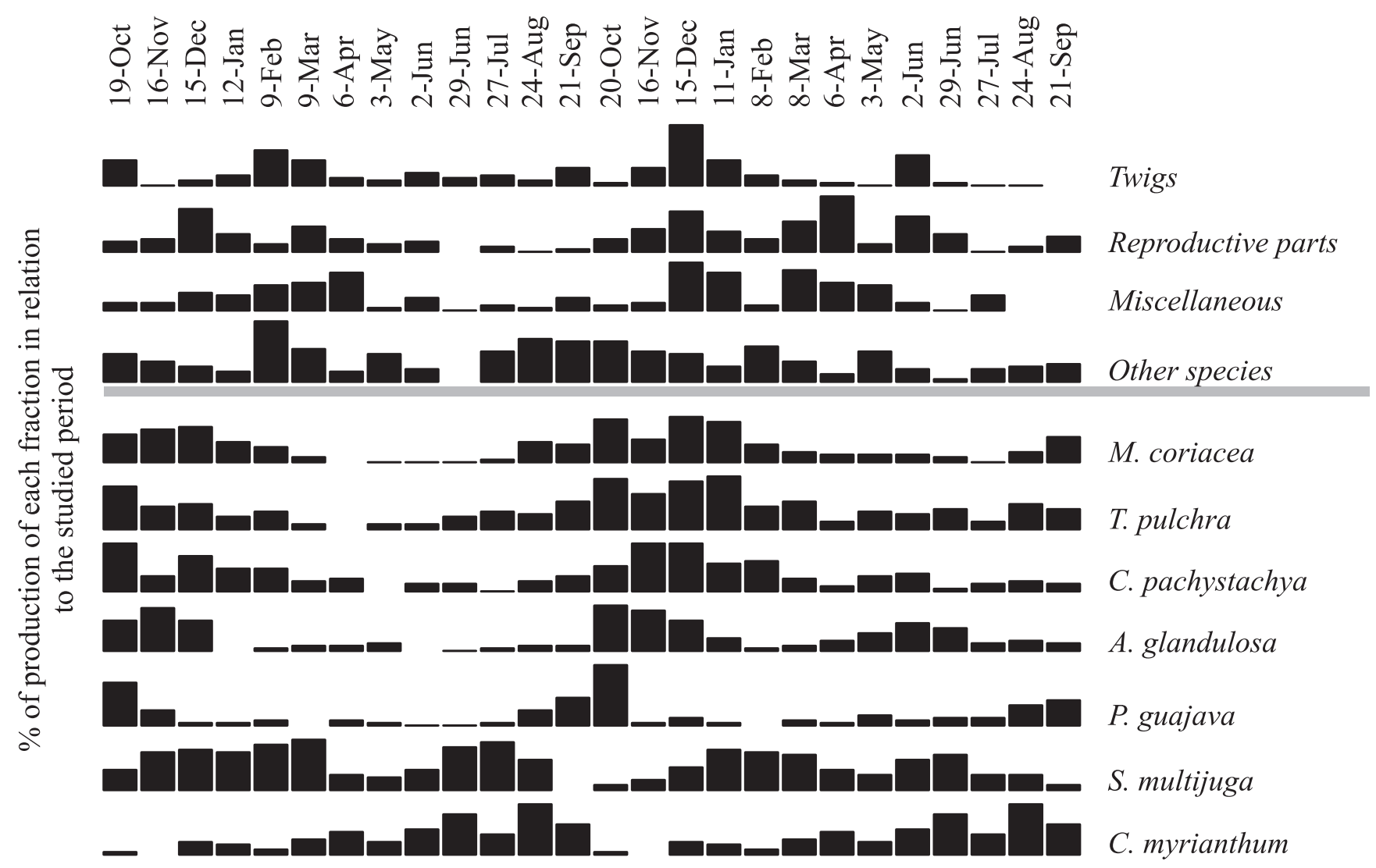

Figure 3. Seasonal pattern of each litter fraction produced, considering the mean of two sites, at RNSM, Guaraqueçaba, Paraná, Brazil. The values of each fraction (\%) are standardized.

The species that present cycles with the highest litterfall at the beginning of the rainy season (spring), preceding basically three months the peaks of the annual cycles of rainfall and temperatures (figure 3 and table 4), such as M. coriacea, C. pachystachya, T. pulchra, A. glandulosa and P. guajava fit the main pattern. Fractions with highest production mainly at the end of the rainy season (summer), such as reproductive parts, twigs, and leaves of $S$. multijuga, correspond to a second pattern. The third pattern, inverse to the other two with litterfall peaks at the end of the non-rainy season (winter), was observed for C. myrianthum.

Other strong correlation coefficients found in table 4 indicate the annual patterns of the studied cycles. 
Table 4. Seasonal patterns detected through correlations (mean for two sites). Higher coefficients were searched through the dislocation of the data sequence of 24 months of production of each litter fraction to match with the data sequences of the 24 months of each meteorological variable (dislocations varying from \pm 1 to \pm 13 months). Shaded cells represent only the highest coefficients. Dark shaded cells represent positive values and light shaded cells represent negative values. The numbers on cells correspond to the main pattern of the community and referred to the correlation coefficients presented below. The intermediary and inverse patterns are represented by the reproductive parts fraction and leaf litterfall of $C$. myrianthum (coefficients not presented, see detailed information in Scheer 2006).

MAIN PATTERN (maximum litterfall at the beginning of rainy season). Total litterfall, total leaf litterfall, leaf litter of $M$. coriacea, C. pachystachya, T. pulchra, A. glandulosa, P. guajava and the other species of the community fit this pattern $(\mathrm{Lp}=$ Litter production).

\begin{tabular}{|c|c|c|c|c|c|c|c|c|c|c|c|c|c|c|c|c|c|c|c|c|c|c|c|c|c|c|}
\hline \multirow{2}{*}{ Meteorological variables } & \multicolumn{13}{|c|}{ Months prior to litter production } & Lp & \multicolumn{12}{|c|}{ Months after litter production } \\
\hline & 13 & 12 & 11 & 10 & 9 & 8 & 7 & 6 & 5 & 4 & 3 & 2 & 1 & 0 & 1 & 2 & 3 & 4 & 5 & 6 & 7 & 8 & 9 & 10 & 111 & $2 \mid 13$ \\
\hline Rainfall (mm) & & & & & 1 & & & & & 7 & & & & & & & 13 & & & & & & 18 & & & \\
\hline Mean temperature $\left({ }^{\circ} \mathrm{C}\right)$ & & & & 2 & & & & & & & 8 & & & & & 14 & & & & & & & & 19 & & \\
\hline Max. temperature $\left({ }^{\circ} \mathrm{C}\right)$ & & & & 3 & & & & & & & 9 & & & & & & 15 & & & & & & & 20 & & \\
\hline Min. temperature $\left({ }^{\circ} \mathrm{C}\right)$ & & & & & 4 & & & & & & 10 & & & & & 16 & & & & & & & & 21 & & \\
\hline Insolation (h day ${ }^{-1}$ ) & & & & & & 5 & & & & & & & 11 & & & & & & 17 & & & & & & & 22 \\
\hline Rel. humidity (\%) & & & & 6 & & & & & & 12 & & & & & & & & & & & & & 23 & & & \\
\hline
\end{tabular}

INTERMEDIARY PATTERN (maximum litterfall at the end of rainy season). Reproductive parts, twigs, and leaf litterfall of S. multijuga fit this pattern.

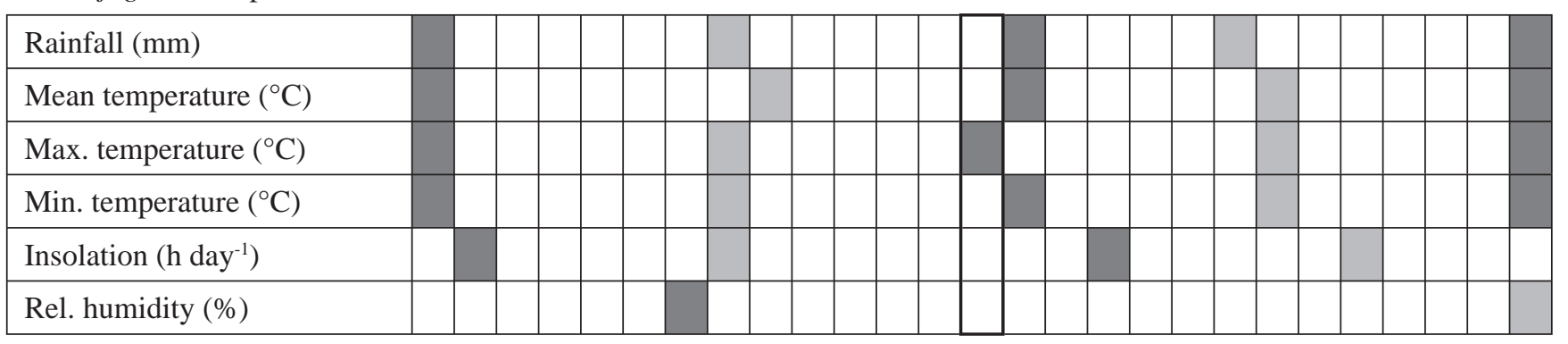

INVERSE PATTERN (maximum litterfall at the end of non-rainy season). Leaf litterfall of C. myrianthum fit this pattern.

\begin{tabular}{|c|c|c|c|c|c|c|c|c|c|c|c|}
\hline \multicolumn{12}{|c|}{ Rainfall (mm) } \\
\hline \multicolumn{12}{|c|}{ Mean temperature $\left({ }^{\circ} \mathrm{C}\right)$} \\
\hline \multicolumn{12}{|c|}{ Max. temperature $\left({ }^{\circ} \mathrm{C}\right)$} \\
\hline \multicolumn{12}{|c|}{ Min. temperature $\left({ }^{\circ} \mathrm{C}\right)$} \\
\hline \multicolumn{12}{|c|}{ Insolation (h day ${ }^{-1}$ ) } \\
\hline \multicolumn{12}{|c|}{ Rel. humidity (\%) } \\
\hline$r_{s}$ & $P<$ & $r_{s}$ & $P<$ & & $r_{s}$ & $P<$ & $r_{s}$ & $P<$ & & $r_{s}$ & $P<$ \\
\hline 1. 0.701 & 0.0005 & 6. -0.725 & 0.0003 & 11. & -0.533 & 0.008 & 16. 0.762 & 0.0001 & 21. & -0.828 & 0.0000 \\
\hline 2. 0.694 & 0.0005 & 7. -0.626 & 0.002 & 12. & 0.606 & 0.002 & 17. 0.455 & 0.023 & 22. & -0.445 & 0.026 \\
\hline 3. 0.704 & 0.0004 & 8. -0.798 & 0.0001 & 13. & 0.712 & 0.0004 & 18. -0.762 & 0.0001 & 23. & 0.493 & 0.0138 \\
\hline 4. 0.697 & 0.0005 & 9. -0.777 & 0.0001 & 14. & 0.727 & 0.0003 & 19. -0.829 & 0.0000 & & & \\
\hline 5. 0.604 & 0.003 & 10. -0.752 & 0.0002 & 15. & 0.731 & 0.0003 & 20. -0.792 & 0.0001 & & & \\
\hline
\end{tabular}




\section{Discussion}

The higher litterfall (6.4 ton ha ${ }^{-1}$ year-1) observed in plots of site 1 lies in the range of studies for Brazilian forests (table 3), even though it is an early to intermediate successional stage. Some studies in Brazilian Atlantic rain forests presented values between 7.9 and 9.4 ton ha ${ }^{-1}$ year1 (Gama-Rodrigues \& Barros 2002, Varjabedian \& Pagano 1988, Oliveira \& Lacerda 1993). For site 2, litterfall (3.0 ton ha $^{-1}$ year-1) was a little lower than in pioneer Atlantic coastal formations (restingas) reported by Moraes et al. (1999), Britez et al. (2005) and Pires et al. (2006). Secondary Atlantic rain forests affected by air pollution presented lower annual litter production, between 1.8 and 5.7 ton ha ${ }^{-1}$ year $^{-1}$ (Leitão-Filho et al. 1993, Domingos et al. 2000). Studies carried out in other Brazilian forests are presented in table 3. Sample size in the present study can be considered satisfactory considering the heterogeneity of the successional process, mainly at site 2 , as can be concluded by the calculated standard errors (table 1 ).

A higher increase of litterfall was observed at the plots of site 2 from the $9^{\text {th }}$ to $10^{\text {th }}$ year of regeneration, as compared to site 1 . It seems to indicate that the difference in litter production between sites was reduced with the advance of succession process. This corroborates the general pattern of biomass increment during succession, a hypothesis discussed by Vitousek \& Reiners (1975) and by Gorham et al. (1979). In a study in the same area (same project), despite the fact that site 1 has a basal area three times higher than site 2, the increment in this structural (phytosociological) descriptor was similar (from the $9^{\text {th }}$ to $10^{\text {th }}$ year of succession), indicating a relatively higher growing rate in this period in site 2 (G. Gatti et al., unpublished data). Also, the increase in the basal area increment from the first to the second year of study was $20 \%$ in site 2 , and only $3 \%$ in site 1 .

The lowest relative contribution of twigs for site 2 is probably related to the low structural parameters of vegetation (density and basal area) and age of trees. Leaf increment stabilizes relatively earlier than woody increment along succession (Vitousek \& Reiners 1975). Therefore, in more advanced stages of succession, biomass increments are driven by woody biomass, decreasing the proportion of leaves (and leaf litter) (Bray \& Gorham 1964, Vitousek \& Reiners 1975). Among other studies in Atlantic Rain Forest (table 3), an average of 71\% (from $59 \%$ to $94 \%$ ) for leaf contribution was observed. The results suggest a less balanced contribution of leaves at the less developed site than at the more developed one, indicating a succession process accompanied by an increase of diversity and a reduction in dominance. This pattern was also observed by Pinto \& Marques (2003) in lowland successional forests over sandy soils in Paraná, Brazil.

The main pattern of leaf litter production is dominated by "leaf-exchanging species", such as $M$. coriacea, T. pulchra and C. pachystachya, a functional type that includes evergreen species in which their young leaves emerge immediately after abscission of old leaves (Borchert et al. 2002). The inverse pattern includes only C. myrianthum classified as a "brevi-deciduous springflushing species", according to Borchert et al. (2002), in which bud break is induced by increasing photoperiod after a brief leafless period in late dry season. Senna multijuga (intermediary pattern) can also be considered as a brevi-deciduous species, although two peaks in leaf litter were observed, one in middle dry season and other in late rainy season.

Peaks in litterfall at the beginning of the rainy season (the main pattern) were observed in other studies in Atlantic rain forests in Brazil (Jackson 1978, Sampaio et al. 1993, Custódio-Filho et al. 1996, Louzada 1997, Moraes et al. 1999, Portes 2001, Gama-Rodrigues \& Barros 2002, Pinto \& Marques 2003, Britez et al. 2005) (table 3). Abscission in evergreen rain forests occurs with more intensity when day length, solar radiation, temperature, air relative humidity, rainfall and consequent leaf flush increases (Larcher 1986, van Schaik et al. 1993). Some tropical and subtropical ecosystems with pronounced seasonality, such as deciduous and semideciduous forests, savannas and some Amazonian forests, generally present the highest leaf litterfall in dry season (Klinge \& Rodrigues 1968, Scott et al. 1992, Cesar 1993, König et al. 2002, Cianciaruso et al. 2006, Silva et al. 2007, Pallardy 2008). However, some of these ecosystems also present peak of leaf fall at the beginning of rainy season or in late dry season (Dias et al. 2002, Pezzatto \& Wisniewski 2006).

The seasonal variations in abscission among these forest types represent the general adaptations of individuals and species to either biotic and abiotic selective factors (van Schaik et al. 1993). Variations in abscission among species and individuals in the same ecosystem as observed in the studied area may also be related to differences in topography and soil type that have a great influence in water availability. The advanced leaf age, the increasing water stress, diminishing nutrient uptake, shortening of the daylight periods, changes in gaseous composition in the atmosphere and consumption by parasitic organisms have an important contribution to leaf senescence 
and consequent abscission (Addicott \& Lyon 1973, Borchert et al. 2002). The leaf senescence can also be a consequence of reproduction or be influenced by competition for resources between the older, lower leaves and upper, younger leaves (Pallardy 2008).

Tropical and subtropical dry forests that present the highest leaf fall gradually earlier than rain forests (as the main pattern of the studied area) are possibly related to the start of senescence process. It seems that such process are triggered earlier by a more severe hydric stress, besides other factors linked to a minor physiological activity of plants that result in abscission. According Borchert et al. (2002), abscission is delayed when older leaves are well-hydrated. For the studied sites, dominated by evergreen species, the maintenance of old leaves during the winter until the increase in flushing in early rainy season seems to be advantageous for production, while the leaf abscission response in deciduous trees in dry forests can provide protection against lethal desiccation to vital meristems, although it occurs at the cost of lost photosynthate (Pallardy 2008). Water stress affects carbohydrate metabolism leading to an increase in sugar concentration of the leaves and this may be associated with osmotic adjustment of plant tissues (Addicott \& Lyon 1973, Pallardy 2008). Abscission zone cells secrete pectinase and cellulase (wall degradation enzymes) (Coder 1999). The protein synthesis and the balance of growth regulators are also affected by water stress. Abscisic acid levels in both roots and shoots increase with tissue dehydration (Addicott \& Lyon 1973, Lin et al. cited by Pallardy 2008) and then stimulate ethylene production and inhibit auxin transport (Coder 1999). In addition to internal forces, gravity and wind tugging on leaves help fracture lines grow (Coder 1999). For the evergreen studied sites a better use of resources during the senescence process seems to occur, while in dry forests this is not possible due to the leafless period. In the present study, both leaf-exchanging and brevi-deciduous species concentrate leafing around the start of the rainy season. According to van Schaik et al. (1993) this avoids the production of new leaves before or during unfavorable conditions.

Leaf fall was also found to be negatively correlated with temperature, rainfall and day length in an average of three months prior in phenological studies at a coastal plain forest (Restinga), nearby the present study area (Marques \& Oliveira 2004) and in other Atlantic Rain Forest types (Morellato et al. 2000). In both studies, the highest leaf fall was also registered at the beginning of the rainy season. This time lag is mainly driven by genotypic adaptation of the species to climatic conditions. As already commented, in this case the adaptation results in shedding of old leaves for the renewal of a photosynthetic surface. Young leaves that have just finished expanding are most efficient at photosynthesis and at controlling transpirational water loss (Pallardy 2008). Nutrient released by decomposition of leaf litter after the start of the rainy season seems to be an important factor in the studied area, considering that nutrient uptake requires active transpiration that can be maximized by new leaves. This ensures an increase in productivity during the most favorable climatic conditions during the warmest and wettest season (van Schaik et al. 1993). In fact, it seems to occur a synchrony among the maximum quantity of newly formed leaves and maximum rainfall, photoperiod and temperatures, as observed by Morellato et al. (2000), Talora \& Morellato (2000) and Marques \& Oliveira (2004).

According to Pallardy (2008), leaf shedding of some tropical trees is strongly influenced by heredity and not so much by small climatic changes. However, Trewavas (2003, 2004) believes that besides genotypic adaptation, plants can also sense very slight gradients of many environmental factors and in this way start their response mechanisms earlier or later in each specific year. The acquired experiences in the course of life of individuals in a community result in different performances (Baldwin 1896) and it can result in morphological and physiological changes affecting their phenology through ontogeny (Osada et al. 2002). In the study area, January is usually the rainiest month according to historical data, but in the two studied years, February was the rainiest month. This phenotypic plasticity of plants, according to Bradshaw (1965) and Addicott \& Lyon (1973), ensures that the physiological result effectively takes place only when environmental conditions are actually favorable, as a pre-adaptation or anticipation mechanism. By responding to a reliable environmental factor, a plant can initiate a developmental response in advance of a change in climate and so optimize phenological timing (van Schaik et al. 1993). These adaptations may have influenced the higher correlation coefficients found in this study, although it has not been possible to test it adequately. Therefore, long term studies (mainly physiological studies) are necessary to bring a better understanding of the processes involved, taking into consideration other factors, such as developmental stage of each plant, longevity of leaves, soil factors as well as larger sampling of each species in the community to minimize errors.

Interestingly enough, most studies on litterfall in tropical forests did not detect strong correlations 
with meteorological data of corresponding months, despite the coincidence of highest litter production with the rainiest and warmest months (CustódioFilho et al. 1996). The lack of correlation is then commonly explained by several authors by the fact that variations in litterfall could be more associated to genetic characteristics and/or historical pedo-climatic conditions than to isolated events in the present. This is also related to the lag time between the changes in climatic conditions that can trigger a plant response (start of senescence process) and the effects (abscission) that can be observed. However, the effort to find strongest correlations through the dislocation of the data sequences of meteorological and biological variables made possible to divide the studied litter fractions into three clear patterns of production.

Finally, the results presented here contribute to provide parameters for diagnosis of the succession in similar and different ecosystems, mainly for primary productivity, carbon and nutrient fluxes. The patterns of production reflect information about the phenology of important pioneer species and it can support programs of seed collection, frugivory and nutrient cycling studies. The stratification of the same alluvial plain was advantageous because confirms that the less developed site may need major attention and intervention through techniques improving regeneration. The stratification also improved the precision of variables estimation and helped to find differences otherwise hard to detect.

Acknowledgments - We thank many professors from the Federal University of Paraná (UFPR) for their helpful comments and suggestions. We are grateful to many colleagues for their substantial help in the field. This research was supported by Fundação O Boticário de Proteção à Natureza. We also thank the Conselho Nacional de Desenvolvimento Científico e Tecnológico (CNPq) and Coordenadoria de Aperfeiçoamento de Pessoal de Ensino Superior (Capes) for providing the scholarship to the first author. We are greatly indebted with Sociedade Fritz Müller de Ciências Naturais (Mülleriana), Meteorological Service of State of Paraná (Simepar) and Forest Sciences Graduation Program at UFPR. We thank Peter Vitousek, Emílo José Scheer Neto and Fernanda Pires Bertuol for helpful comments on the manuscript.

\section{References}

ADDICOTT, F.T. \& LYON, J.L. 1973. Physiological ecology of abscission. In Physiological ecology: a series of monographs, texts and treatises (T.T. Kozlowski, eds.). Academic Press, New York, p.85-123.
BALDWIN, J.M. 1896. A new factor in evolution. American Naturalist 30:441-451.

BORCHERT, R., RIVERA, G. \& HAGNAUER, W. 2002. Modification of vegetative phenology in a tropical semi-deciduous forest by abnormal drought and rain. Biotropica 34:27-39.

BRADSHAW, A.D. 1965. Evolutionary significance of phenotypic plasticity in plants. Advances in Genetics 13:115-155.

BRAY, J.R. \& GORHAM, E. 1964. Litter production in forests of the world. Advances in Ecological Research 2:101-157.

BRITEZ, R.M., PIRES, L., REISSMANN, C.B., PAGANO, S.N., SILVA, S.M., ATHAYDE, S.F. \& LIMA, R.X.L. 2005. Ciclagem de nutrientes na planície costeira. In História natural e conservação da Ilha do Mel (M.C.M. Marques and R.M. Britez, eds.). Editora UFPR, Universidade Federal do Paraná, Curitiba. p.145-168.

BROWN, S. \& LUGO, A. 1982. The storage and production of organic matter in tropical forest and their role in the global carbon cycle. Biotropica 14:161-187.

CESAR, O. 1993. Produção da serapilheira na mata mesófila semidecídua da Fazenda Barreiro Rico, Município de Anhembi, SP. Revista Brasileira de Biologia 53: 671-681.

CHAPMAN, C.A., CHAPMAN, L.J., STRUHSAKER, T.T., ZANNE, A.E., CLARK, C.J. \& POULSE, J.R. 2005. A long-term evaluation of fruiting phenology: importance of climate change. Journal of Tropical Ecology 21:31-45.

CIANCIARUSO, M.V., PIRES, J.S.R., DELITTI, W.B.C. \& SILVA, E.F.L.P. 2006. Produção de serapilheira e decomposição do material em um cerradão na Estação Ecológica de Jataí, município de Luiz Antônio, SP, Brasil. Acta Botanica Brasilica 20:49-59.

CODER, K.D. 1999. Falling tree leaves: leaf abscission. University of Georgia School of Forest Resources, Athens.

CUSTÓDIO FILHO, A., FRANCO, G.A.D.C., POGGIANI, F. \& DIAS, A.C. 1996. Produção de serapilheira e o retorno de macronutrientes em floresta pluvial atlântica Estação Biológica de Boracéia, São Paulo, BR. Revista do Instituto Florestal 8:1-16.

DIAS, H.T., FIGUEIRA, M.D., SILVEIRA, V., FONTES, M.A.L., OLIVEIRA FILHO, A.T. \& SCOLFORO, J.R.S. 2002. Variação temporal de nutrientes na serapilheira de um fragmento de floresta estacional semidecidual montana em Lavras. Cerne 8(2):1-17.

DOMINGOS, M., MORAES, R.M., STRUFFALDI-DE VUONO, Y. \& ANSELMO, C.E. 1997. Produção de serapilheira e retorno de nutrientes em um trecho de Mata Atlântica secundária, na Reserva Biológica de Paranapiacaba, SP. Revista Brasileira de Botânica 20:91-96. 
DOMINGOS, M.L., SILVEIRA, M.I.M. \& STRUFFALDIDE-VUONO, Y. 2000. Nutrient cycling disturbance in Atlantic Forest sites affected by air pollution coming from the industrial complex of Cubatão, Southeast Brazil. Revista Brasileira de Botânica 23:77-85.

EMBRAPA - empresa brasileira de pesquisa em agropecuária. 2006. Sistema brasileiro de classificação de solos. Embrapa, Centro Nacional de Pesquisas em Solos (2 ${ }^{\mathrm{a}}$ ed.), Rio de Janeiro.

FUNDAÇÃO SOS MATA ATLÂNTICA. 1998. Atlas da evolução dos remanescentes florestais e ecossistemas associados no domínio da Mata Atlântica no período de 1990-1995. SOS Mata Atlântica, São Paulo.

GAMA-RODRIGUES, A.C. \& BARROS, N.F. 2002. Ciclagem de nutrientes em floresta natural e em plantios de eucalipto e de dandá no sudeste da Bahia, Brasil. Revista Árvore 26:193-207.

GATTI, G. 2000. Composição florística, fenologia e estrutura da vegetação de uma área em restauração ambiental, Guaraqueçaba, Paraná. Dissertação de mestrado, Universidade Federal do Paraná, Curitiba.

GOLLEY, F.B., MCGINNIS, J.T., CLEMENTS, R.G., CHILD, G.I. \& DUEVER, M.J. 1978. Ciclagem de minerais em um ecossistema de floresta tropical úmida. EDUSP, São Paulo.

GORHAM, E., VITOUSEK, P.M. \& REINERS, W.A. 1979. The regulation of chemical budgets over the course of terrestrial ecosystem succession. Annual Review of Ecology and Systematics 10:53-84.

IAPAR - Instituto Agronômico do Paraná. 2005. Cartas climáticas de estado do Paraná - classificação segundo W.Köppen.http://www.iapar.br/Sma/Cartas_Climaticas/ Classificacao_Climatica.htm (access in 07/15/2005).

JACKSON, J.F. 1978. Seasonality of flowering and leaf-fall in a Brazilian subtropical lower montane moist forest. Biotropica 10:38-42.

KLINGE, H. \& RODRIGUES, W.A. 1968. Litter production in an area of Amazonian terra firme forest. I - Litter fall, organic carbon and total nitrogen contents of litter. Amazoniana 1:287-301.

KÖNIG, F.G., SCHUMACHER, M.V., BRUN, E.J. \& SELING, I. 2002. Avaliação da sazonalidade da produção de serapilheira numa floresta estacional semidecidual no município de Santa Maria-RS. Revista Árvore 26: 429-435.

LARCHER, W. 1986. Ecofisiologia vegetal. Editora Pedagógica e Universitária, São Paulo.

LEITÃO-FILHO, H.F., PAGANO, S.N., CESAR, O., TIMONI, J.L. \& RUEDA, J.J. 1993. Ecologia da Mata Atlântica em Cubatão. Editora da UNESP, São Paulo.

LOUZADA, M.A.P. 1997. O aporte de matéria orgânica ao solo em floresta atlântica de tabuleiros, Linhares (ES): ritmo fenológico e papel da diversidade arbórea. M.Sc. Thesis, Universidade Federal do Rio de Janeiro, Rio de Janeiro.
MAACK, R. 1968. Geografia física do estado do Paraná. M. Roesner, Curitiba.

MARQUES, M.C.M. \& OLIVEIRA, P.E.A.M. 2004. Fenologia de espécies do dossel e do sub-bosque de duas florestas de Restinga na Ilha do Mel, sul do Brasil. Revista Brasileira de Botânica 27:713-723.

MARQUES, M.C.M., ROPER, J.J. \& SALVALAGGIO, A.P.B. 2004. Phenological patterns among plant lifeforms in a subtropical forest in southern Brazil. Plant Ecology 173:203-213.

MAZUREC, A.P. \& VILLELA, D.M. 1998. Produção e camada da serrapilheira em uma mata atlântica na Serra do Imbé, norte fluminense, em diferentes altitudes. In Simpósio de ecossistemas brasileiros 4. (S. Watanabe, coord.). ACIESP, São Paulo, v.3, p.36-42.

MORAES, R.M., DELITTI, W.B.C. \& STRUFFALDI-DEVUONO, Y. 1999. Litterfall and litter nutrient content in two Brazilian tropical forests. Revista Brasileira de Botânica 22:9-16.

MORELLATO, L.P.C., TALORA, D.C., TAKAHASI, A., BENCKE, C.C., ROMERA, E.C. \& ZIPPARRO, V.B. 2000. Phenology of Atlantic Rain forest trees: a comparative study. Biotropica 32:811-823.

MYERS, N., MITTERMEIER, R.A., MITTERMEIER, C.G., FONSECA, G.A. \& KENT, J. 2000. Biodiversity hotspots for conservation priorities. Nature 403:853858.

OLIVEIRA, R.R. \& LACERDA, L.D. 1993. Produção e composição química da serapilheira na Floresta da Tijuca, RJ. Revista Brasileira de Botânica 16:93-99.

OSADA, N., TAKEDA, H., FURUKAMA, A. \& AWANG, M. 2002. Ontogenetic changes in leaf phenology of a canopy species, Elateriospermum tapos (Euphorbiaceae), in a Malaysian rain forest. Journal of Tropical Ecology 18:91-105.

PALLARDY, S.G. 2008. Physiology of woody plants. $3^{\text {rd }}$ ed. Academic Press, Columbia.

PEZZATTO, A.W. \& WISNIEWSKI, C. 2006. Produção de serapilheira em diferentes seres sucessionais da Floresta Estacional Semidecidual no oeste do Paraná. Revista Floresta 36:111-120.

PINTO, C.B. \& MARQUES, R. 2003. Aporte de nutrientes por frações de serapilheira em sucessão ecológica de um ecossistema da floresta atlântica. Revista Floresta 33:257-264.

PIRES, L.A., BRITEZ, R.M., MARTEL, G. \& PAGANO, S.N. 2006. Produção, acúmulo e decomposição da serapilheira em uma restinga da Ilha do Mel, PR, Brasil. Acta Botânica Brasilica 20:173-184.

PORTES, M.C.G.O. 2001. Deposição de serapilheira e decomposição foliar em floresta ombrófila densa altomontana, Morro Anhangava, Serra da Baitaca, Quatro Barras, PR. M.Sc. Thesis, Universidade Federal do Paraná, Curitiba. 
RIBEIRO, M.C., METZGER, J.P., MARTENSEN, A.C., PONZONI, F.J., HIROTA, M.M. 2009. The Brazilian Atlantic Forest: How much is left, and how is the remaining forest distributed? Implications for conservation. Biological Conservation 142:11411153.

SAMPAIO, E.V.S.B, DALL'OLIO, A., NUNES, K.S. \& PINTO, E.E. 1993. A model of litterfall, litter layer losses and mass transfer in a humid tropical forest at Pernambuco, Brazil. Journal of Tropical Ecology 9:291301.

SCHEER, M.B. 2006. Ciclagem de nutrientes em um trecho de Floresta Ombrófila Densa Aluvial em regeneração, Guaraqueçaba, PR. Dissertação de mestrado, Universidade Federal do Paraná, Curitiba.

SCHEER, M.B. 2009. Fluxo de nutrientes pela precipitação pluviométrica em dois trechos de floresta ombrófila densa em Guaraqueçaba, Paraná. Revista Floresta 39:117-130.

SCOTT, D.A., PROCTOR, J. \& THOMPSON, J. 1992. Ecological studies on a lowland evergreen rain forest on Maraca Island, Roraima, Brazil. II - Litter and nutrient cycling. Journal of Ecology 4:705-717.

SEMA - Secretaria Estadual do Meio Ambiente e Recursos Hídricos. 2002. Mapeamento da Floresta Atlântica do estado do Paraná. Sema, Curitiba.

SILVA, C.J., SANCHES, L., BLEICH, M.E. \& LOBO, F.A. 2007. Produção de serrapilheira no Cerrado e Floresta de Transição Amazônia-Cerrado do Centro-Oeste Brasileiro. Acta Amazonica 37:543548 .
TALORA, D.C. \& MORELLATO, L.P.C. 2000. Fenologia de espécies arbóreas em floresta de planície litorânea do sudeste do Brasil. Revista Brasileira de Botânica 23:13-26.

TREWAVAS, A. 2003. Aspects of plant intelligence. Annals of Botany 92:1-20.

TREWAVAS, A. 2004. Aspects of plant intelligence: an answer to Firn. Annals of Botany 93:353-357.

VANSCHAIK, C.P., TERBORGH, J.W.\&WRIGHT, S.J.1993. The phenology of tropical forests: adaptive significance and consequences for primary consumers. Annual Review of Ecology and Systematics 24:353-377.

VARJABEDIAN, R. \& PAGANO, S.N. 1988. Produção e decomposição de folhedo em um trecho de mata atlântica de encosta no município de Guarujá, SP. Acta Botanica Brasilica 1:243-256.

VELOSO, H.P., RANGEL FILHO, A.L. \& LIMA, J.C.A. 1991. Classificação da vegetação brasileira, adaptada a um sistema universal. IBGE, Departamento de Recursos Naturais e Estudos Ambientais, Rio de Janeiro.

VITOUSEK, P.M. \& REINERS, W.A. 1975. Ecosystem succession and retention: a hypothesis. BioScience 25:376-381.

VITOUSEK,P.M.1984.Litterfall, nutrientcycling, and nutrient limitation in tropical forests. Ecology 65:285-298.

VOGT, K.A., GRIER, C.C. \& VOGT, D.J. 1986. Production, turnover, and nutrient dynamics of above- and belowground detritus of world forests. Advances in Ecological Research 15:303-377.

ZAR, J.H. 1999. Biostatistical analysis. Prentice-Hall, New Jersey. 